20.

\title{
Analysis of Radiation Intensity and Sunshine Duration in the Karst Area of Maros TN Bantimurung Bulusaraung South Sulawesi During Solstice Phenomenon
}

\author{
Muhammad Arsyad ${ }^{1 *}$, Rihan Muhammad Al Ghifari ${ }^{1}$, Agus Susanto1, Pariabti Palloan ${ }^{1}$, Sulistiawaty ${ }^{1}$ \\ ${ }^{1}$ Department of Physics, Mathematics and Natural Science, Universitas Negeri Makassar, Indonesia
}

DOI: $10.29303 /$ jppipa.v7iSpecialIssue.1068

\section{Article Info}

Received: October 27th, 2021

Revised: November $25^{\text {th }}, 2021$

Accepted: December 6th 2021

\begin{abstract}
This study aims were to analyze the profile of radiation intensity and sunshine duration in the karst area of Maros TN Bantimurung Bulusaraung, South Sulawesi during solstice phenomenon in the period 2011-2020. In addition, radiation intensity and sunshine duration in the same area were also measured. A Pearson correlation shows that the intensity of solar radiation and the sunshine duration have a bimodal pattern. The average radiation intensity during the 2011-2020 solstices in June and December was $1.193 \frac{\mathrm{Joule} / \mathrm{cm}^{2}}{\text { Day }}$ and 1.249 $\frac{\text { Joule } / \mathrm{cm}^{2}}{\text { Day }}$, respectively. Whereas the percentage of sunshine duration in June and December reached $54 \%$ and $35 \%$, respectively. The results of the Pearson correlation analysis of the relationship between radiation intensity and sunshine duration in June were 0.722 , while in December, it was 0.717 . The interpretation results show that the two parameters have a strong correlation and have a close relationship.
\end{abstract}

Keywords: Radiation Intensity; Sunshine Duration; Solstice; Bimodal; Pearson.

Citation: Arsyad, M., Alghifari, R.M., Susanto, A., Palloan, P., \& Sulistiawaty. (2021). Analysis of Radiation Intensity and Sunshine Duration in the Karst Area of Maros TN Bantimurung Bulusaraung South Sulawesi During Solstice Phenomenon. Jurnal Penelitian Pendidikan IPA, 7(Speciallssue), 199-204. https://doi.org/10.29303/ippipa.v7iSpecialIssue.1068

\section{Introduction}

Solar radiation is electromagnetic energy radiation consisting of electric and magnetic fields that have wavelengths between $0.15-3.0 \mu \mathrm{m}$. This energy is received by the earth's surface converted from light to heat. The earth's surface absorbs some heat that warms the surface and partially is reflected back into space (Jemaa, et al., 2013). There are five factors affect the sun's irradiation reaching to the earth's surface such as the duration of solar irradiation, the angle of sunlight, the location of latitude, atmospheric clarity, relief of the earth's surface, and distance from the sea.

As a country located in the equator, Indonesia has abundant sunlight every year, with average radiation intensity about $4.8 \mathrm{kWh} / \mathrm{m}^{2}$ a day and an average radiation length of 12 hours a day (Octavianti, et al., 2018). In case of the karst area of Maros TN Bantimurung Bulusaraung, South Sulawesi, which is located between 119 $34^{\prime} 17^{\prime \prime}-119^{\circ} 55^{\prime} 13^{\prime \prime} B L$ and $4^{\circ} 42^{\prime} 49^{\prime \prime}-$ $5^{\circ} 06^{\prime} 42^{\prime \prime}$ LS, the availability of solar radiation is about 133.518 grams.cal $/ \mathrm{m}^{2}$ in a year (Rifai, et al., 2014).

The sunshine duration indicates the duration of sunshine in given period (usually, a day or a year) for a certain location on Earth. Whereas the intensity of radiation is the amount of energy received by a surface area per unit of area and unit of time (Suehrcke, et al., 2013). The differences amount of solar radiation intensity in various places on the earth's surface can cause wind patterns that will affect air temperature, rainfall, and air pressure. Furthermore, the sunshine duration and intensity of solar radiation will affect weather and climate conditions, particularly when the solstice and equinox occurs due to the pseudomovement of the sun and the position of latitude at a certain area.

The solstice takes place when the sun's apparent path is farthest north or south from the earth's equator.

\footnotetext{
*Email: $\underline{\text { m_arsyad288@unm.ac.id }}$
} 
The summer solstice occurs on June $20^{\text {th }}$ or $21^{\text {st }}$ in which the North Pole is tilted most directly towards the Sun. While the winter solstice takes place on December $21^{\text {st }}$ or $22^{\text {nd }}$ in which the South Pole is tilted most directly towards the Sun. In these cases, the difference between day and night reaches the maximum (Araki, et al., 2017). Whreas the equinox is an event that occurs when the length of the day is equal to the length of the night when the sun is directly above the equator (Matuszko and Weglarczyk, 2014). The equinox occurs when the sun is located directly above the equator. In areas that have high geographical latitudes (e.g $66.5^{\circ}$ south latitude), the sun will be above the horizon for 24 hours or the sun never sets at the winter sol (Yuliatmaja, 2009).

The geographical coordinate determine the radiation intensity and sunshine duration received by a certain area. According to Panjaitan, (2011), the more water content in the cloud, the higher the albedo value. A small albedo value results in a large radiation intensity and vice versa. It can be deduced that the cloud cover will affect the sunshine duration. The size of sunshine duration is proportional to the intensity of solar radiation.

Information about the potential availability of solar energy is an essential in supporting optimal solar energy utilization, such as the design of building thermal architecture, energy utilization systems (photovoltaic (PV), solar concentrator, solar collector), etc. Moreover, by understanding the characteristic of radiation intensity and the sunshine duration at certain areas can be used to assess the potential of the utilization of solar energy.

The aim to this paper is to analyze the profile of radiation intensity and sunshine duration. In addition, the relationship between radiation intensity and sunshine duration in the karst area of Maros TN Bantimurung Bulusaraung during the solstice was determined using Pearson correlation analysis. Radiation intensity data and the sunshine duration are important elements of climate parameters. Therefore, Information about the climate is needed, especially in the Karst Maros Area since the formation of karst areas including the process of dissolving rocks is affected by the climate change (Arsyad, et al., 2014). The climate change also has a significant role on controlling the rate of karstification process (Haryono, 2013).

\section{Method}

The study focused on elements of atmospheric physics that state weather and climate, namely the sunshine duration and intensity of solar radiation. The data used in this study was obtained from the Maros Climatology (Class I) Station.
The research procedures for this study are as follows:

\section{Preparatory Stage}

The preparatory stage includes researching literature related to solstice phenomena related to climate parameters such as radiation intensity and the sunshine duration in Indonesia.

\section{Data collection stage}

The data collection stage is secondary data in the form of monthly average data for the last ten years (2011 to 2020) radiation intensity and sunshine duration.

\section{Data Analysis Stage}

The data analysis stage includes (3) three stages, namely the first stage, plotting a graph of radiation intensity, long-time solar irradiation data, and eye declination day to obtain radiation intensity profile and length of solar irradiation in karst Maros TN area. Babul Period 2011-2020 based on the apparent motion of the sun. The declination of the sun is obtained using the following equations.

$$
\delta=23,45 \sin \left(\frac{360}{365}(284+n)\right)
$$

where $\delta$ is an angle of declination of the sun $\left(^{\circ}\right)$ and $n$ is a Julian day

The second stage is the grouping of radiation intensity data and the sunshine duration into two parts, namely during the solstice (June and December) and outside the solstice (March and September) presented in the form of tables. The third stage is carried out with Pearson correlation analysis to obtain the correlation coefficient between radiation intensity and the length of solar irradiation during the solstice. The correlation coefficient equation $\left(\mathrm{r}_{\mathrm{xy}}\right)$ is as follows.

$$
r_{x y}=\frac{n \sum X_{i} Y_{i}-\left(\sum X_{i}\right)\left(\sum Y_{i}\right)}{\sqrt{\left\{n \sum X_{i}^{2}-\left(\sum X_{i}\right)^{2}\right\}\left\{n \sum Y_{i}^{2}-\left(\sum Y_{i}\right)^{2}\right\}}}
$$

where $r_{x y}$ is a Pearson coefficient, $X_{i}$ is Free variable (predictor) (intensity of solar Radiation), $Y_{i}$ is variable bound (response) (length of solar Irradiation), and $n$ is Lots of data. Sugiyono, (2007) states that the strength index of the relationship between the two variables $X$ and $Y$ is as follows.

Table 1. Variable Relationship Strength Index $X$ and $Y$

\begin{tabular}{llll}
\hline Value $\mathrm{r}_{\mathrm{xy}}$ & Interpretation & Value $_{\mathrm{xy}}$ & Interpretation \\
\hline $0.00-0.19$ & Very low & $(-0.00)-(-0.19)$ & Very low \\
$0.20-0.39$ & Low & $(-0.20)-(-0.39)$ & Low \\
$0.40-0.59$ & Medium & $(-0.40)-(-0.59)$ & Medium \\
$0.60-0.79$ & Strong & $(-0.60)-(-0.79)$ & Strong \\
$0.80-1.00$ & Very strong & $(-0.80)-(-1.00)$ & Very strong \\
\hline
\end{tabular}




\section{Result and Discussion}

Solar Radiation Intensity and Sunshine Duration Profile in Karst Maros TN Bantimurung Bulusaraung Area Period 2011-2020.

Data on the average monthly solar radiation intensity for the period 2011-2020 conducted a graphical analysis of the angle of declination of the sun. Based on the study of the data, the power of solar radiation follows the pattern of the sun's pseudo-daily motion declination. An analysis of the average monthly solar radiation intensity profile over ten years can be seen in Figure 1.

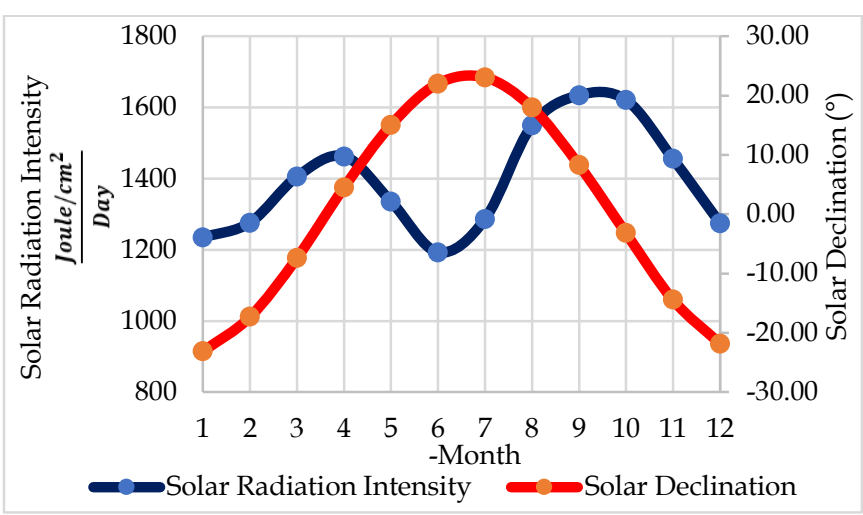

Figure 1. Graph of Monthly Average Solar Radiation Intensity in Karst Maros TN Bantimurung Bulusaraung Area during the periods of 2011-2020.

Figure 1 shows the profile of the monthly average solar radiation intensity profile in the Karst area of Maros TN Bantimurung Bulusaraung during the 20112020 periods that varies according to the sun's position (solar declination). The solar radiation intensity profile has a bimodal pattern with the highest peaks occurring in April and September of $1.462 \frac{\mathrm{Joule} / \mathrm{cm}^{2}}{\text { Day }}$, and $1.634 \frac{\mathrm{Joule} / \mathrm{cm}^{2}}{\text { Day }}$, while the lowest peak was at January and June were $1.235 \frac{\mathrm{Joule} / \mathrm{Cm}^{2}}{\text { Day }}$, and $1.193 \frac{\mathrm{Joule} / \mathrm{cm}^{2}}{\text { Day }}$, respectively.

From January to March, the radiation intensity increases along with the sun's declination towards the minimum. While in April to June, the power of radiation decreases along with the sun's declination towards the maximum. Furthermore, from July to September, the intensity of radiation increases, and from October to December, the power of radiation decreases. This is following the research conducted by Wida, et al. (2019, in March-April and August-September, the solar radiation intensity graph increases as the sun approach the equator, in contrast the solar radiation intensity graph decreases as the sun moves away from the equator in July-June and December-January.

Bimodal patterns are formed due to the influence of the sun's pseudo-motion. The sun in its pseudo-daily period will result in a change in declination in the sky.
This is because the earth has an ecliptic tilt with a celestial equator of 23.5 degrees. The annual solar trajectory tilts towards the celestial equator with a declination of +23.5 degrees or a declination of +-23.5 degrees. Differences in solar declination that occur result in changes in the intensity of solar radiation in a year.

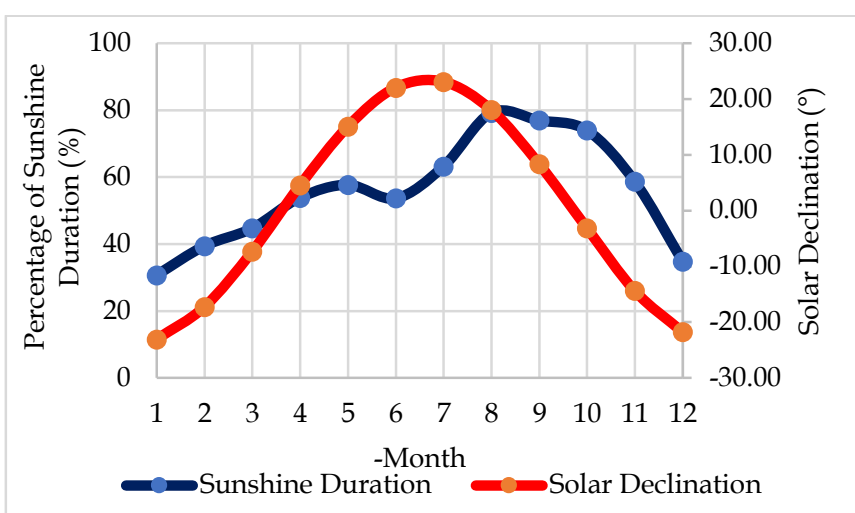

Figure 2. Graph of Monthly Average Sunshine Duration in Karst Maros TN Bantimurung Bulusaraung Area During periods of 2011-2020

The data of the average monthly sunshine duration for the period 2011-2020 conducted a graphical analysis of the angle of declination of the sun. Based on the data analysis, obtained the sunshine duration also follows the pattern of declination of the sun's pseudodaily motion. An analysis of the old profile of the average monthly sunshine duration for ten years can be seen in the following two images.

Figure 2 shows the old profile of monthly average sunshine duration in the Karst Maros TN Bantimurung Bulusaraung Region from 2011-2020, varying following the sun's position (declination of the sun). The old profile of sunshine duration obtained has a bimodal pattern, with the highest peaks occurring in May and August at $48 \%$ and $66 \%$, respectively. While the lowest peaks in January and June were $26 \%$ and $45 \%$, respectively. From January to April, the sunshine duration increases along with the sun's declination towards the minimum. From May to June, the irradiation size decreases along with the sun's declination towards the maximum. Furthermore, the length of solar irradiation increases from June to August, and from September to December, the size of sunshine duration decreases. This is following research conducted by Islammiyati and Sutikno, (2019). In the month and August-September, the sunshine duration tends to be maximum as the sun heads to the equator. Conversely, in December-January, the old graph of sunshine duration tends to be minimal along with the sun's equator.

The highest peak of the long-standing sunshine duration occurs when the eastern monsoon is maximum. The lowest peak occurs when the western monsoon is 
full. But in June, the lowest peak of solar irradiation is not affected by the eastern monsoon winds, but rather the sun's position in the northern hemisphere, so the southern hemisphere, especially in the Karst Maros TN Bantimurung Bulusaraung Region with latitude positions 4-5 south latitude experience a shorter duration of day than night.

\section{Radiation Intensity and Sunshine Duration during the Solstice in Karst Maros TN Bantimurung Bulusaraung Period 2011-2020.}

The average intensity of solar radiation during the solstice in June reached $1.193 \frac{\text { Joule } / \mathrm{cm}^{2}}{\text { Day }}$. In December it reached $1.249 \frac{\mathrm{Joule}_{\mathrm{cm}} \mathrm{cm}^{2}}{\text { Day }}$, then the sunshine duration in June the percentage reached $54 \%$, and in December the percentage reached $35 \%$. The profile analysis showed that the average monthly radiation intensity did not correspond to the length of monthly sunshine duration in June and December. This is seen from high radiation intensity in December did not cause the size of solar irradiation to be higher. This happens because the position of the Karst Maros TN Babul Region is geographically at 4-5 southern latitudes. In December, the radiation intensity is high due to the sun's position on the south side of the earth. While in June, the sun is at the northern equinox of the planet (far from the equator), so the analysis results obtained the average radiation intensity in December is higher than in June. But not so with 2011, 2013, and 2020 due to the three years in December maximum cloud cover (minimum sunshine duration), affecting radiation intensity readings. Furthermore, the size of sunshine duration in June is greater than in December. This happens because December is the transition from the dry season to the rainy season, so clouds are formed that will potentially block sunlight.

Table 2. Solar Radiation Intensity and Sunshine Duration during the Solstice measured in the Karst Maros TN Bantimurung Bulusaraung Area in the Period of 2011-2020.

\begin{tabular}{lllll}
\hline \multirow{2}{*}{ Year } & \multicolumn{2}{l}{$\begin{array}{l}\text { Solar Radiation } \\
\text { Intensity }\end{array}$} & $\left.\begin{array}{l}\text { joule } / \mathrm{cm}^{2} \\
\text { day }\end{array}\right)$ & \multicolumn{2}{l}{$\begin{array}{l}\text { Percentage of } \\
\text { Sunshine Duration }(\%)\end{array}$} \\
\cline { 2 - 5 } & June & Desember & June & Desember \\
\hline 2011 & 1.106 & 908 & 55 & 21 \\
2012 & 830 & 1.148 & 48 & 34 \\
2013 & 1.175 & 983 & 55 & 22 \\
2014 & 1.139 & 1.150 & 49 & 34 \\
2015 & 1.061 & 1.173 & 56 & 42 \\
2016 & 1.454 & 1.527 & 57 & 43 \\
2017 & 976 & 1.450 & 45 & 38 \\
2018 & 1.344 & 1.495 & 51 & 38 \\
2019 & 1.442 & 1.443 & 62 & 56 \\
2020 & 1.406 & 1.217 & 59 & 21 \\
Average & 1.193 & 1.249 & 54 & 35 \\
\hline
\end{tabular}

In addition to being influenced by the cloud cover factor and the latitude position of an area, the radiation intensity is also influenced by the sun's distance to the sun. In December, the high intensity of radiation is due to the Earth's position towards the closest point to the sun (perihelion). While in June, the position of the Earth towards the farthest point with the sun (aphelion). So the intensity of radiation in December is higher than in June.

The Karst Maros TN Bantimurung Bulusaraung area is geographically around the Earth's equator. The radiation intensity and the irradiation length are potentially maximum when the sun's position is directly above the equator (commonly known as equinox). Equinox takes place twice each year, around 20 March and 23 September.

The average intensity of solar radiation in the Karst Maros TN Bantimurung Bulusaraung area in the period of 2011-2020 during equinox i.e. in March and September were $1.406 \frac{\text { Joule } / \mathrm{cm}^{2}}{\text { Day }}$ and $1.634 \frac{\mathrm{Joule} / \mathrm{cm}^{2}}{\text { Day }}$, respectively. Whereas the percentage of the sunshine duration during equinox i.e. in March and September were $45 \%$ and $77 \%$, respectively.

Measurements data showed the average monthly radiation intensity corresponded to the average monthly sunshine duration during equinox. During equinox, the higher the intensity of the radiation, the higher the solar irradiation. The Karst Maros region has a position close to the equator results in higher values of solar radiation intensity and percentage of sunshine duration compared to during the solstice phenomena. Measurement data results of solar radiation intensity and sunshine duration during equinox measured in karst Maros TN Bantimurung Bulusaraung Period 2011-2020 is given in Table 3.

Table 3. Solar Radiation Intensity and Sunshine Duration during equinox measured in karst Maros TN Bantimurung Bulusaraung Period 2011-2020.

\begin{tabular}{|c|c|c|c|c|}
\hline \multirow[t]{2}{*}{ Year } & \multicolumn{2}{|c|}{$\begin{array}{l}\text { Solar Radiation } \\
\text { Intensity }\left(\frac{\text { Joule } / \mathrm{cm}^{2}}{D a y}\right)\end{array}$} & \multicolumn{2}{|c|}{$\begin{array}{l}\text { Percentage of Sunshine } \\
\text { Duration }(\%)\end{array}$} \\
\hline & March & September & March & September \\
\hline 2011 & 1.038 & 1.301 & 35 & 74 \\
\hline 2012 & 1.188 & 1.330 & 38 & 74 \\
\hline 2013 & 1.165 & 1.505 & 54 & 78 \\
\hline 2014 & 1.222 & 1.616 & 49 & 86 \\
\hline 2015 & 1.359 & 1.472 & 50 & 88 \\
\hline 2016 & 1.734 & 1.741 & 50 & 67 \\
\hline 2017 & 1.455 & 1.807 & 37 & 71 \\
\hline 2018 & 1.614 & 1.969 & 43 & 78 \\
\hline 2019 & 1.656 & 1.959 & 45 & 87 \\
\hline 2020 & 1.624 & 1.639 & 46 & 68 \\
\hline Average & 1.406 & 1.634 & 45 & 77 \\
\hline
\end{tabular}


Analysis of Solar Radiation Intensity Relationship and Sunshine Duration during Solstice in Karst Maros TN Bantimurung Bulusaraung Region Period 2011-2020 using Pearson Correlation Analysis.

Pearson correlation analysis was done using equation 2. The Pearson correlation analysis of radiation intensity and sunshine duration during the solstice obtained a large coefficient correlation between the power of solar radiation and the size of solar irradiation in table 4 below.

Table 4. The results of the Pearson Correlation Coefficient of Solar Radiation Intensity and Sunshine Duration during the Solstice in the Karst Maros TN Bantimurung Bulusaraung Area Period 2011-2020.

\begin{tabular}{llll}
\hline No & Month & $\begin{array}{l}\text { Pearson } \\
\text { Correlation } \\
\text { Coefficient }\end{array}$ & Interpretation \\
\hline 1 & June & 0.722 & strong \\
2 & December & 0.717 & strong \\
\hline
\end{tabular}

Pearson's correlation analysis results in June obtained a coefficient of 0.722 with a strong correlation interpretation, and then in December received a coefficient of 0.717 with a strong correlation interpretation. The analysis showed that radiation intensity affected the sunshine duration with a strong interpretation of correlation. Then the results of the correlation analysis obtained a positive correlation number, and the number interpreted that the two parameters have a close relationship, meaning that the high radiation intensity will result in the length of irradiation being high. Thus, when the solstice occurs in the Karst Region of Maros, Bantimurung Bulusaraung National Park for 2011-2020, the radiation intensity affects the duration of solar irradiation with a strong correlation, and the correlation coefficient is positive.

\section{Conclusion}

The radiation intensity profile and length of solar irradiation period 2011-2020 in the Karst Maros TN Bantimurung Bulusaraung Region has a bimodal pattern. The average solar radiation intensity- during the June and December solstices, respectively, reached $1.193 \frac{\mathrm{Joule} / \mathrm{cm}^{2}}{\mathrm{Day}}$ and $1.249 \frac{\mathrm{Joule} / \mathrm{cm}^{2}}{\mathrm{Day}}$. While the average sunhine duration in June and December, the percentage reached $54 \%$ and $35 \%$, respectively. Pearson correlation analysis results obtained 0.722 (June) and 0.717 (December).

\section{References}

Araki, K., Lee, K. H., \& Yamaguchi, M. (2017). Bandgaps of multi-junction solar cells potentially determined at the sun height of the culmination on the winter solstice. Solar Energy, 153, 445-453. doi:https://doi.org/10.1016/j.solener.2017.05.09 $\underline{4}$.

Arsyad, M., Pawitan, H., Sidauruk, P., \& Putri, E. I. K. (2014). Analisis Ketersediaan Air Sungai Bawah Tanah Dan Pemanfaatan Berkelanjutan Di Kawasan Karst Maros Sulawesi Selatan. J. Manusia Dan Lingkungan, 21(1), 8-14. doi: https://doi.org/10.22146/jml.18505

[Indonesiann]

Haryono, E. (2013). Perkembangan Tema Riset Geomorfologi Karst dalam Perspektif Iklim. Paper presented at Pertemuan Ilmiah Tahunan XVI, Banjarmasin. [Indonesian]

Islammiyati, A., \& Sutikno. (2019). Analisis Potensi Energi Matahari Menggunakan Data Lama Penyinaran Matahari (LPM) Kota Pontianak. Prisma Fisika, 7 (3), 238-245. doi: http://dx.doi.org/10.26418/pf.v7i3.37408 [Indonesiann]

Jemaa, A.B., Rafa, S., Essounbouli, N., Hamzaoui, A., Hnaien, F., \& Yalaoui, F. (2013). Estimation of Global Solar Radiation Using Three Simple Methods. Energy Procedia, 42 (2013), 406-415. doi: https://doi.org/10.1016/j.egypro.2013.11.041.

Matuszko, D., \& Weglarczyk, S. (2014). Relationship between sunshine duration and air temperature and contemporary global warming. Internasional Journal of Climatology. 35 (12), 3640-3653. doi: https://doi.org/10.1002/joc.4238.

Octavianti, A., Muliadi, \& Apriansyah. (2018). Estimasi Intensitas Radiasi Matahari di Wilayah Kota Makassar. Prisma Fisika, 6 (3), 152-159. doi: http://dx.doi.org/10.26418/pf.v6i3.28711 [Indonesiann]

Panjaitan, A. L. (2011). Estimasi Energi Radiasi Matahari Bulanan dan Tahunan dengan Model Solar EnergyAir Temperature. Bandung. Institut Teknologi Bandung. [Indonesian]

Rifai, L. D., Tongkuyut, S. H. J., \& Raharjo, S. S. (2014). Analisis Intensitas Radiasi Matahari di Manado dan Maros. Jurnal MIPA UNSRAT, 3 (1), 49-52. doi : $\quad$ https://doi.org/10.35799/jm.3.1.2014.3907 [Indonesiann]

Suehrcke, H., Bowden, R.S., \& Hollands, K.G.T. (2013). Relationship between sunshine duration and solar radiation. Solar Energy, 92, 160-171. doi: https://doi.org/10.1016/j.solener.2013.02.026.

Sugiyono. (2007). Statistika Untuk Penelitian. Bandung: ALFABETA. [Indonesian]

Wida, D.A.K., Sumaja, K., \& Wiguna, P.P.H. (2019). Analisis Hubungan Intensitas Radiasi Dan Lama Penyinaran Matahari Dengan Parameter Cuaca Di Stasiun Meteorologi Ngurah Rai Serta Pengaruhnya Terhadap Potensi Pembangkit 
Listrik Tenaga Surya Di Bali Selatan. Meteo Ngurah Rai, 5 (1) 1-7. [Indonesiann]

Yuliatmaja, M.R. (2009). Kajian Lama Penyinaran Matahari Dan Intensitas Radiasi Matahari Terhadap Pergerakan Semu Matahari Saat Solstice di Semarang. Semarang: Universitas Negeri Semarang. Retrieved from http://lib.unnes.ac.id/2141/ [Indonesian] 